\section{A survey of acrylic sheet in Portuguese art collections}

\section{Levantamento de obras de arte em chapa acrílica em coleções Portuguesas}

SARA BABO ${ }^{1^{*}}$ (D)

JOANA LIA FERREIRA ${ }^{1}$-(D)

1. Department of Conservation and Restoration and Research Unit LAQV-REQUIMTE, NOVA School of Science and Technology (FCT NOVA), 2829-516 Monte da Caparica.

"sara.sbabo@gmail.com

\begin{abstract}
Acrylic sheet, also known by the commercial names Plexiglas or Perspex, consists of poly(methyl methacrylate) (PMMA). Attractive to artists since its development in the 1930s, it became especially popular during the 1960s. In Portugal, knowledge about its use by artists and its condition is scarce. In this work, the main Portuguese art collections were surveyed with the goal of gaining an overview of the use of acrylic sheet in the Portuguese art context and its current condition. The paper describes the methodology used and the results obtained regarding 137 artworks by 69 different artists registered as containing acrylic. Results show that this material is being used by Portuguese artists at least since the 1960s. It has been used in several artistic forms, from painting and sculpture to photography, installation, objects/reliefs, and artist books. Most of the artworks were in good or fair condition. The main problems observed were dust and dirt deposits, abrasion, and scratches.
\end{abstract}

\section{Resumo}

A chapa acrílica, também conhecida pelos nomes comerciais Plexiglas ou Perspex, consiste em poli(metacrilato de metilo) (PMMA). Atractiva para os artistas desde o seu desenvolvimento na década de 1930, popularizou-se durante a década de 1960. Estudos sobre a sua utilização e estado de conservação são escassos em Portugal. Realizou-se um levantamento nas principais coleções de arte portuguesas com o objetivo de obter uma visão geral da presença e estado da chapa acrílica nesse contexto. É descrita a metodologia utilizada e os resultados obtidos relativamente a 137 obras de 69 artistas, inventariadas como contendo acrílico. Os resultados mostram que este material tem sido utilizado pelos artistas portugueses pelo menos desde os anos 60 até aos dias de hoje, em diversas formas artísticas, que vão desde a pintura e a escultura à fotografia, instalação, objetos/relevos e livros de artistas. A maioria das obras encontra-se em bom ou razoável estado. Os principais danos observados foram depósitos de poeira e sujidade, abrasões e riscos.

\section{KEYWORDS}

Acrylic

Poly(methyl methacrylate)

Collections survey

Condition survey

Plastics conservation

Contemporary art

\section{PALAVRAS-CHAVE}

Acrílico

Poli(metacrilato de metilo) Conservação de plásticos

Levantamento de coleções

Levantamento do estado

de conservação

Arte contemporânea 


\section{Introduction}

Collection surveys are a fundamental tool for collection management including preservation and conservation planning. The objective and systematic data that can be generated by a survey are essential to assess and prioritize preservation needs [1-2], but can also be useful in pointing out directions for research in conservation. This has been the case in the conservation of plastics artefacts, as may be confirmed by analyzing the publications in this field. During the late 1980 s and early 1990s, when plastics conservation started to be seen as an urgent need and, consequently, to develop as a professional speciality, surveys were fundamental to raise awareness of the presence of these materials in several types of collections and of the problems associated to them [3-6]. Surveys have also helped to identify the most problematic plastics in collections $[4,6-8]$ and to define priorities in research $[5,9]$. Material identification based on date and type of object, appearance (e.g. transparency, colour, surface finish) and physical properties such as hardness and smell has been a common procedure $[4,7,10]$. Nowadays, surveys in collections with plastics have become more common [10-14] and recent publications have been focusing on the methodologies developed for its efficient performance [12-14]. Unfortunately, in Portugal, this trend has not been followed and, to the best of our knowledge, there are no publications reporting the amount and condition of plastic artefacts in national collections.

One of the plastics that may be found in museum collections is acrylic sheet, which consists mainly of poly(methyl methacrylate), PMMA, and was developed industrially in the early 1930s [15]. Due to its remarkable optical qualities, stiffness and good weathering resistance, it gained the name of "organic glass" [16-17]. Commercial names such as Plexiglas and Perspex are also commonly used to identify this material. In addition to its clarity and availability in different colours, other PMMA properties such as light weight and ability to be easily thermoformed, cut or glued, made this material also attractive to artists. Naum Gabo and other members of the Russian avant-garde were some of the few artists who started to explore the potential of this new material already in the 1930s, to substitute the less stable cellulose nitrate and cellulose acetate; but acrylic sheet was practically not seen in artworks until the 1960s, when plastics in general became widely spread in society [18-19].

In the conservation field, PMMA is considered a very stable plastic [20-23]; nevertheless, it is not immune to damage. Results from other surveys published in the literature [24, p. 298, 25] show that acrylic sheet objects are very susceptible to scratching.

The present work is part of a broader project which concerns the conservation of acrylic sheet in artworks. As a first step, it was considered fundamental to have an overview of the use of this material in the Portuguese art context and its current condition. Considering the lack of published information, a survey on the main Portuguese art collections was carried out. Therefore, in contrast to the most common prac- tice, it was not intended to survey several plastics in a specific collection, but to survey a specific plastic, acrylic sheet, in several collections.

The main goals of the survey were:

- To have an overview of the artworks with acrylic sheet in Portuguese art collections (Which types of works were made? By which artists? From which dates?).

- To assess the type of acrylic sheet employed (e.g. coloured or transparent).

- To assess the condition of this material in the collections (What is its condition? What are the main damages observed?).

- To guide subsequent research to the main conservation problemsobserved.

This paper describes the methodology used for the survey and the results obtained. Besides providing data on artworks made with acrylic sheet, its condition and the major damages detected, it also intends to reduce the gap of knowledge about the presence of plastics in Portuguese art collections.

\section{Methodology}

\section{Collections surveyed}

Since the focus of this study was the use of acrylic sheet in artworks, only collections of modern and contemporary art were selected. Collections of applied arts and design were deliberately left out of this survey, even though acrylic sheet would certainly be found in these collections as well. For the survey, both public and private collections were considered as long as they are open to the general public. The main modern and contemporary art collections in Portugal were surveyed:

- Centro de Arte Moderna - Fundação Calouste Gulbenkian (CAM-FCG);

- Coleção António Cachola - Museu de Arte Contemporânea de Elvas (MACE);

- Coleção de Arte Fundação EDP (FEDP);

- Coleção da Caixa Geral de Depósitos (CGD);

- Coleção Manuel de Brito, acervo Centro de Arte Manuel de Brito (CAMB);

- Coleção de Serralves;

- Museu Coleção Berardo (MCB);

- Museu Nacional de Arte Contemporânea do Chiado (MNAC). It is important to note that each collection has its own characteristics and specificities, which will consequently influence the results of the survey. For example, the collections of CAM-FCG, MCB and MNAC, have artworks representative of all the decades of the twentieth century [26-28]; the collections of FEDP, CGD, CAMB, and Serralves [29-32] are focused on art produced from the 1960 s onwards; and MACE collection includes mainly artworks produced in the last 25 years by artists that only started to exhibit regularly since the 1980s [33]. Regarding the geographic origin of the artworks or the artists represented, CAM-FCG and MCB have international collections, while the others are mainly focused in Portuguese art. CGD collection has the particularity of 
including contemporary art from Portuguese speaking countries, such as Brazil, Mozambique, Angola and Cape Verde [30].

During the survey, differences between the several collections were also found in what concerns the access to artworks, which resulted in examinations with different degrees of coverage. At MACE, MCB, CGD, CAMB, CAM-FCG, and MNAC, it was possible to examine directly all the artworks registered as containing acrylic sheet, except when they were physically inaccessible. At Serralves, it was only possible to examine a selection of 10 artworks out of the 45 previously identified as containing this material; and at FEDP, it was impossible to have access and examine the artworks. Objects that were not examined directly could only be considered for the first part of this survey, and were not included in the database developed within the present survey and described hereafter.

\section{Development of the survey database}

A relational database was developed using FileMaker Pro 12 software, in order to input and organize all the information collected during the survey. In line with the goals previously defined, the survey was divided in two major parts: 1) Identification of artworks made of or containing parts/elements in acrylic sheet; 2) Assessing the condition of the acrylic sheet parts within those artworks and identifying its main damages. This division is reflected in the FileMaker database, which was organized in two linked parallel tables, Figure 1. General information from the artworks, such as author, date, typology, provenance, marks and inscriptions, materials, and general description, was collected on the Artworks table. Fields for information relative to the overall condition, previous restoration treatments, storage and housing descriptions, images and other additional details were also included. The number of acrylic sheet parts/elements present in the artwork was also reported, and this field establishes a link to the files in the Acrylic elements table. On this second table, detailed information about each element was collected including type, colour, transparency, thickness, and transformation processes used. Data related to the condition and types of damage on the acrylic elements were gathered as well, in a total of 46 fields. When possible, the fields in the database were designed using pop-up menus, drop-down lists and checkbox sets to facilitate filling and guaranty consistency in the use of terms and grades, which helped subsequent data treatment.

Condition grades, nomenclature regarding damage types, and damage grades were based on the survey model developed in the framework of the European project POPART [24]. Both artworks and acrylic elements condition were graded in one of four categories: good, fair, poor and unacceptable. Damage types were divided in three main classes: 1) colour changes, 2) deposits and 3) mechanical problems. Each specific damage (e.g. yellowing, dust, scratch) was graded in four categories: 1) minor and/or limited; 2) more important but occasional; 3) general but minor; 4) severe and general damage. More details about the grading system and description of the specific types of damage may be found in the literature [10, 34, pp. 271-274].

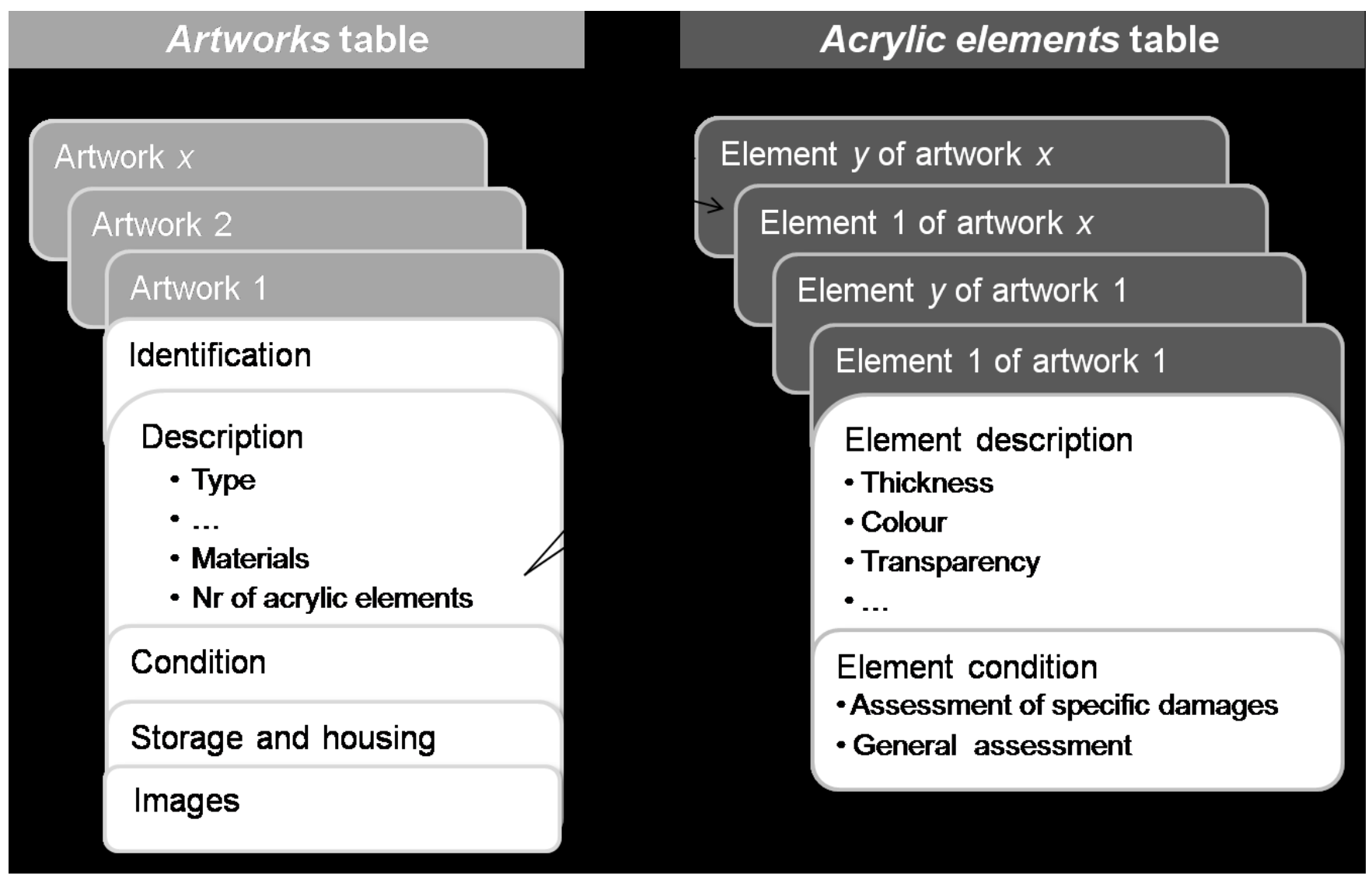

Figure 1. Organization of the database with the two connected tables. 


\section{Survey method}

The survey consisted of four steps:

1) identifying all possible artworks in the collection that might contain elements in acrylic sheet;

2) examine each object and/or the respective elements in acrylic sheet;

3) adding the collected information to the database;

4) data treatment.

The first step consisted of searching for all the objects that might have acrylic sheet in each collection. This search was done previously by the conservators of the collections (in the case of CGD, CAMB, Serralves, and MNAC) or by using the collection database in situ (MCB) or online (MACE, FEDP, CAM-FCG). On the collections databases, search was conducted using several terms: acrylic sheet, acrylic glass, acrylic, plexiglas, perspex, plastic, etc. It became clear that the information related to the materials of the artworks registered in the databases is often incomplete or incoherent. As a result, in some cases, artworks were added to the initial selection during the course of the second step, either by talking to the museum staff who would remember about other objects, or by finding new objects while working in the storage areas.

Any individual component of the artwork in acrylic was considered as an element. Exceptions to this rule were plinths, boxes or frame glazing that were neither original nor fundamental for the object exhibition.

Material identification was based on the museum and artist information, and eventually on examination based on appearance and feel. Acrylic sheet is a relatively simple plastic to identify since there are not many other plastics available in flat thick sheets with similar hardness and optical characteristics, as shown by the results of previous surveys. The higher price and inferior resistance to yellowing of polycarbonate does not make it an attractive alternative to PMMA for artists, while the cheaper polystyrene has inferior optical properties and is easily distinguished from PMMA by its characteristic sound when tapped.

Examination of each artwork and acrylic element was conducted by visual observation, with the help of raking light and optivisors. All data collected was introduced in the FileMaker database for easy consultation and exported afterwards to Excel software. Several photographs were taken of each object, particularly of the observed damages.

This survey was conducted in different periods between 2014 and 2019. Therefore, it should be kept in mind that meanwhile more artworks with acrylic sheet may have been introduced in the collections and that the condition of some of the objects observed could have changed.

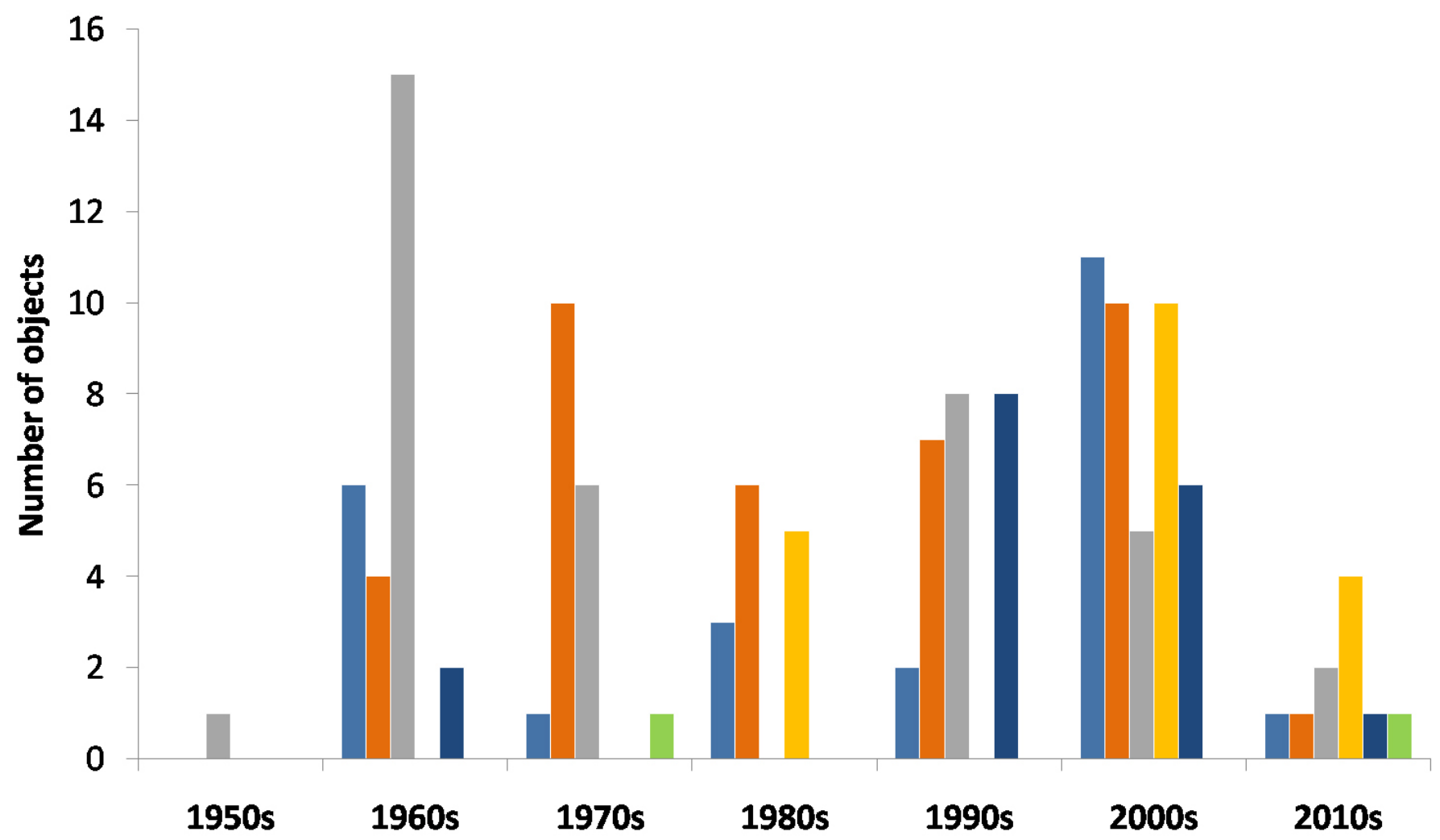

Painting Sculpture $\square$ Object/Relief $\square$ Photography $\square$ Instalation $\square$ Book

Figure 2. Number of artworks distributed by typology per decade of production. Total number of objects considered was 137. 


\section{Results and Discussion}

During the survey, 137 artworks were identified as being made of or containing parts made of acrylic sheet. Of these, 45 belong to Serralves, 30 to CAM-FCG, 15 to CGD, 14 to MACE, 13 to FEDP, 10 to MNAC, 8 to CAMB, and 2 to MCB. Only 89 of the 137 artworks were possible to examine directly; consequently, only these were considered for the Artworks table in which detailed data was collected and condition assessment performed. In these 89 artworks, 244 individual elements in acrylic sheet were identified and were considered for the Acrylic elements table.

Images of most of the artworks referred may be seen on the websites of the collections, searching by the name of the authors [26-29, 32-33].

\section{Overview of the works of art with acrylic sheet}

Several types of artworks were found which were divided by six typologies: painting, sculpture, object/relief, photography, installation, and book. This was not always straightforward since some of the artworks are in between typologies. For example, Lourdes Castro artworks were registered as paintings in CAM-FCG and as sculpture in Serralves collection. In this survey, it was decided to consider as an object/ relief any artwork that should be seen on a wall (as a painting) but has an important three-dimensional component, as some of these artworks by Lourdes Castro. From the 137 artworks with acrylic sheet detected during the survey, the majority consisted of sculpture ( $28 \%$ ) and objects/relief (27\%). The remaining typologies are distributed in descending order as follows: painting (18\%), photography (14\%), installation (12\%) and book (1\%).
Figure 2 presents the typologies of artworks organized per date of production. It is possible to note that the type of artworks produced in acrylic sheet has varied over the decades, which can be related with the artistic tendencies of the times. For example, during the 1960 s it may be seen a profusion of objects/reliefs, which resulted from the loosening of the defined and exclusive categories of painting and sculpture that were used until then [35] and, in particular, from the "objectualization" of painting that was followed by Portuguese artists of diverse movements during that decade [36, p. 39]. Examples of artworks in this category found during the survey were produced by the British artists Peter Blake, Anthony Hill, and Gillian Wise, or by the Portuguese artists Lourdes Castro, João Vieira and Eduardo Nery.

The introduction of new techniques in the art field is also reflected in the results; a good example is the face-mounted photograph. This technique consists in the permanent adhesion of a sheet of PMMA to the surface of the photographic print, with either a double-sided pressure-sensitive film or a silicone rubber and primer system. The technique was developed and patented in the early 1970s, in Switzerland, as the Diasec procedure and became a tendency in photography in the mid-1980s in Germany [37]. In Figure 2 it is possible to observe that photography typology appears during the 1980 s in the collections. This results exclusively from five artworks using the Diasec process by Julia Ventura, who was working in the Netherlands during that decade. Excluding her artworks, photographs mounted with this type of technique only became common in Portugal after 2000 . In fact, the Diasec process is proprietary, and very few licences were sold by the owners to other studios in the world. However, with the increased popularity of this type of mounting, similar

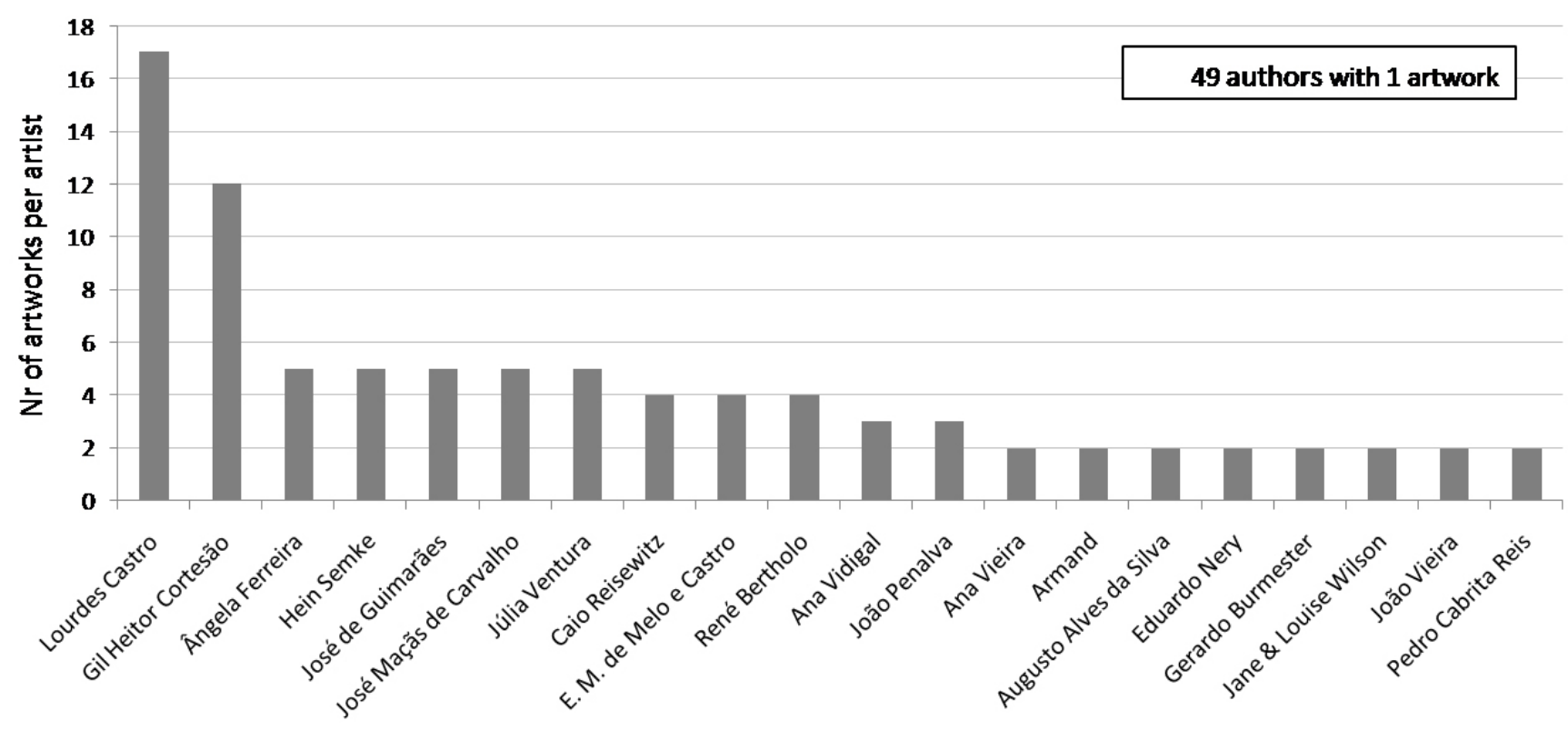

Figure 3. Number of artworks distributed by authors. Total number of objects considered was 137. 

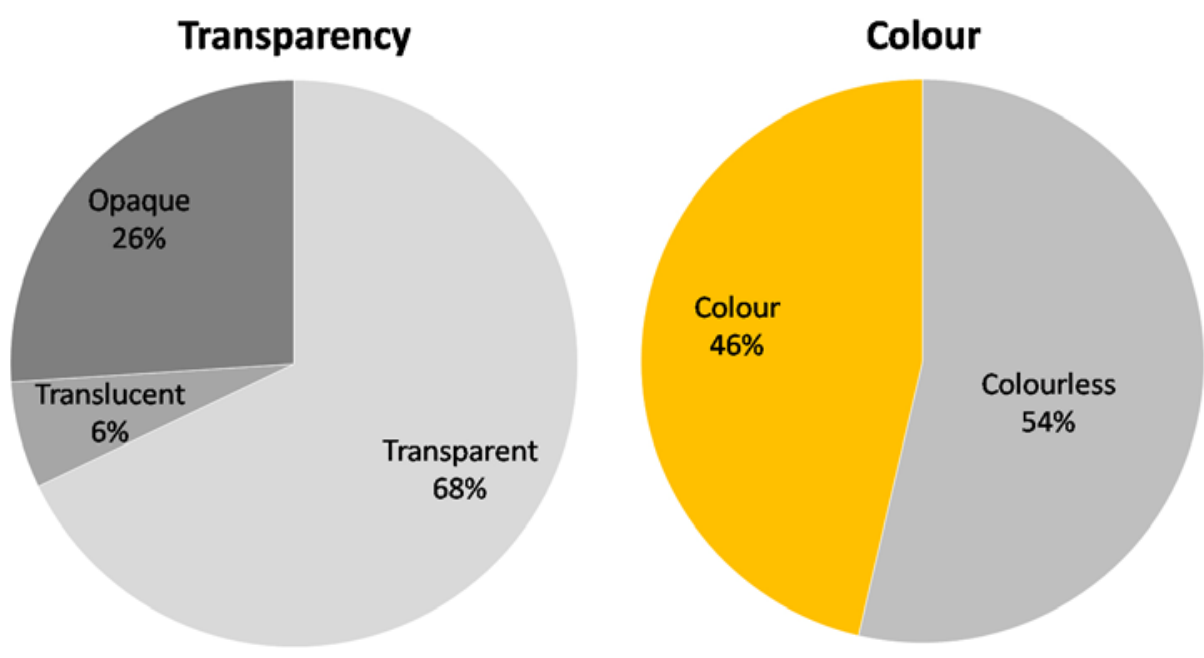

Figure 4. Types of acrylic sheet found during the survey regarding transparency (left) and colour (right). Total number of acrylic elements considered was 244 , from 89 objects.

processes that are not protected by a license were developed and started to be offered by many more printing and mounting studios around the year 2000 [37], which may explain the results.

Regarding production dates, the majority of the artworks surveyed $(31 \%)$ was created during the first decade of the new century. Further analysis of the results displayed in Figure 2 shows a similar trend to what is described in the literature about the relation of plastics with art: plastic was hardly noticed as an artistic material until the 1960; it experienced a boom in the mid-1960s, when not only plastics but the technology and knowledge to process them became more accessible; its use decreased during the 1970s, partially because of health concerns but also because the feeling of novelty associated to the material was lost; and started to gain importance again after the 1980s, when it became established as just another available material in the artists' palette [18]. The results relative to the artworks produced during the last decade (2010s) are not conclusive due to the proximity with the dates of the survey.

Besides the typology and the date of the artworks produced with acrylic, it is also interesting to note which authors have chosen this material, Figure 3. In this survey 69 different artists were counted. Unsurprisingly, the majority was Portuguese, with 48 authors. The oldest artworks surveyed were by British artists: White Faced Relief(1959) by Mary Martin, Love Wall (1961) by Peter Blake, ReliefConstruction C7(2) (1963) by Anthony Hill, and ReliefConstruction (1964) by Gillian Wise, all from the CAM-FCG. The oldest artwork found by a Portuguese artist is from 1964, In the Café, by Lourdes Castro, also from CAM-FCG. The artist was working in Paris since 1958, and that has probably facilitated her access to acrylic sheet.

Interestingly, Lourdes Castro is also the most represented artist in this survey, with 17 artworks, including 15 paintings and objects/reliefs produced during the 1960s. Moreover, these artworks were found in all the collections surveyed except one, MACE (focused on art produced after 1980), which underlines the relevance of her work in acrylic sheet during that decade.

The second most represented artist is Gil Heitor Cortesão, with 12 paintings produced between 1998 and 2016. The artist has mastered a technique of reverse painting with oil on acrylic sheet. His paintings are present in four of the eight collections surveyed.

Reference should also be made to Ângelo de Sousa, who was a precursor in the use of this material as well. His sculpture from 1965, untitled, from CAM-FCG, has the particularity of being made with acrylic sheets modelled with heat in three-dimensional forms. This was the only artwork found during the survey using this technique.

\section{Types of acrylic sheet used by the artists}

Figure 4 presents an overview of the type of acrylic sheets used by the artists regarding transparency and colour of the material. As can be seen from the image, the majority of the elements surveyed consisted of transparent $(68 \%)$ and colourless (54\%) acrylic sheet.

Acrylic sheet simultaneously transparent and colourless was the most commonly found (51\%). This may be explained by the fact that, in many of the artworks observed, the acrylic was used as a painting support or as a protection barrier (as in Diasec mounted photographs) and, therefore, "invisibility" was the characteristic preferred. In contrast, coloured elements, both opaque and transparent, were used in sculpture, object/relief and installation artworks, mostly during the 1960s and 1970s decades. Several colours were chosen by the artists, including fluorescent colours in artworks by Lourdes Castro, René Bertholo, João Vieira and Ana Hatherly (all produced between the mid-1960s and 1971), and a brilliant red in the artwork by Ângelo de Sousa (1965). The use of brilliant or lustrous sheets by Ângelo de Sousa was conditioned by the type of material available in Portugal during 

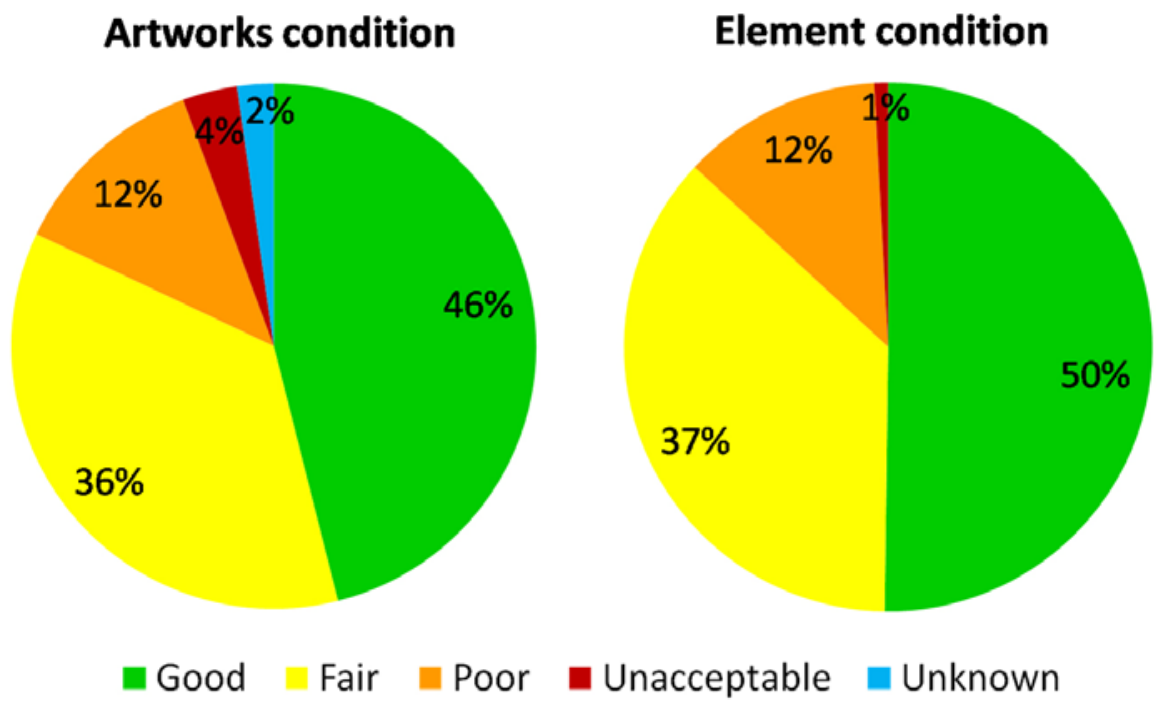

Figure 5. Condition of the artworks and of the elements in acrylic surveyed. Total number of artworks considered was 89 and of the elements in acrylic 244.

that period. It is known that acrylic sheets were produced mainly for the button industry and therefore there was a preponderance of lustrous sheets [38-39]. Regarding the thickness of the sheets surveyed, values ranging from $1 \mathrm{~mm}$ to $15 \mathrm{~mm}$ were found, but by far the majority of the sheets are of $3 \mathrm{~mm}$ (42.6\%).

Condition of the artworks and the elements in acrylic sheet Two types of condition assessment were performed: of the artwork as a whole and of each individual acrylic element. The results obtained are summarised in Figure 5. Most of the artworks are in a good and fair condition ( $82 \%$ ), but this percentage is even higher when considering only the acrylic elements (87\%). In the other extreme are the artworks and the acrylic elements considered in an unacceptable condition, $4 \%$ and $1 \%$, respectively. Acrylic elements alone are in a slightly better condition than the artworks where they belong. Artworks considered in an unacceptable condition presented severe damages such as a fracture on the acrylic sheet, but also paint delamination, which does not correspond to a bad condition of the acrylic element. Regarding the artworks evaluated in a poor condition, it should be noted that the majority corresponds to artworks produced before 1980, i.e. the group of the oldest artworks surveyed, therefore not surprising. The same tendency was observed for the acrylic elements in the same category. Artworks counted as unknown correspond to two installations composed of several objects, from which only the ones in acrylic were observed.

These values are difficult to compare with others published in the literature because data regarding specifically acrylic sheet condition are scarce and discrepant. Surveys are usually not specific to this type of plastic. As a result, in the two surveys known that present quantitative results specific for the acrylic sheet condition (art collections of the Stedelijk Museum [10] and the Pinacoteca de S. Paulo [11]), the num- ber of objects with this material was low, 18 and 15, respectively, which hinders significant results. Two other factors may contribute to the discrepancy of results. First, the condition grading of the objects is dependent on the type and period of collection [10]. Second, to grade is a subjective process, and different people may evaluate the same object in different ways, even though they might be using the same scales and parameters.

Figure 6 provides an overview of the specific damages observed, with the number of occurrences in each grade. Damages were divided in different groups: colour changes, deposits, and mechanical problems. The most prevalent types of damage detected belong to the two last groups and were dirt and dust deposits and abrasions. Regarding dirt, finger marks were especially relevant and often observed. Abrasion was the type of damage with more "severe and general damage" (grade 4) occurrences. This agrees with what was reported in the POPART project [24, p. 298], even though they refer to scratch only, i.e. there was no differentiation between scratch and abrasion in that study. In the same study, stain was the second most important damage observed, which was not verified in the present survey. Although breaks, or fractures, do not present many occurrences, they are the specific damages that led to the assessment as "unacceptable condition" of $1 \%$ of the acrylic elements surveyed (Figure 5), which corresponds to two acrylic sheets of two different artworks examined. Regarding colour and gloss changes, it is important to note that most of the occurrences marked in these fields were related to deposits (dust and dirt) on the acrylic surfaces, and not with a discoloration phenomenon of the material.

A relation between type of acrylic (colour, transparency, thickness) and condition or type of damages could not be established. The results show that most of the damages observed result from external factors, such as deficient housing, improper maintenance and incorrect handling. 


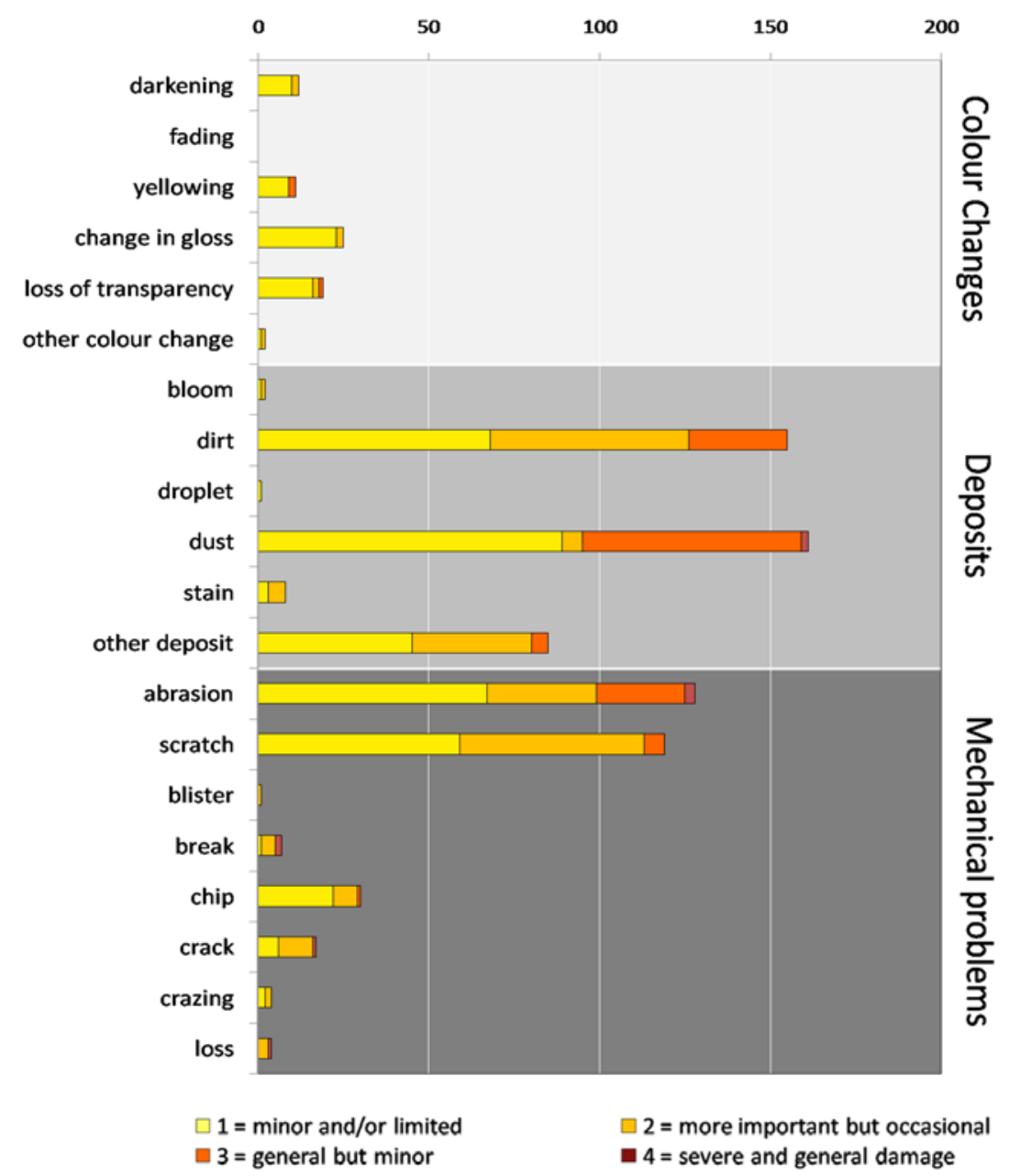

Figure 6. Damages observed in the acrylic elements organized in three main categories. Number of occurrences and damage grades is presented in the bars.

\section{Conclusions}

The main goals of the survey presented in this paper were to contribute to the knowledge about the use of acrylic sheet by the Portuguese artists, to assess the presence and condition of artworks made with this material in Portuguese art collections, and to identify its main damages.

The 137 artworks studied provided a general picture of the use of this material. The results have shown that acrylic sheet is a material used by the Portuguese artists at least from the 1960 s to the present day. It was used in paintings, sculptures, objects/reliefs, photography, installations and even artist books. At least 48 Portuguese authors have used it somehow in their artworks, and from these, a more restricted group of artists has explored the properties of PMMA in a more consistent way, e.g. Lourdes Castro and Gil Heitor Cortesão. Lourdes Castro is especially relevant since she was probably the first Portuguese artist to use acrylic sheet in her artworks. Ângelo de Sousa also deserves notice for being author of the sole artwork surveyed in which acrylic sheets were transformed in three-dimensional shapes using heat.

Regarding the condition assessment, most of the artworks and acrylic elements were in good or fair condition; nonetheless some problems were detected. The main problems observed were dust and dirt deposits, abrasion and scratches, which result from a combination of known characteristics of the material (e.g. tendency to form static electricity, poor scratch resistance) and external factors such as inappropriate housing, handling and cleaning, besides eventual accidents. These results show that for the future preservation of acrylic sheet, more attention should be given to the "human factor" this is, in training museum staff in dealing with these fragile objects. In addition, given the extreme sensitivity of acrylic to abrasion and scratch, conservation research should continue on the development of safer cleaning methodologies.

As further work, it could be relevant to confirm by infrared spectroscopy if all assessed elements are of PMMA. Although unlikely, especially in art collections, other polymers such as polycarbonate and polystyrene could be present since they are also used to produce transparent sheets. According to other surveys [10-11], their presence in works of art is a minority in relation to PMMA.

The methodology used for this survey may be applied to other classes of plastics in similar studies. The comparison between results obtained for different plastics could be extremely interesting for several areas besides conservation 
and museum management, such as art history or material culture studies.

\section{Acknowledgments}

The authors would like to thank to the staff of the art collections studied, who have authorized survey the artworks and gave assistance during the process, namely: Patrícia Machado from MACE; Isabel Corte-Real and Maria Manuel Conceição from CGD; Rui Brito and Ana Paula Migalhada from CAMB; Ana Vasconcelos, Patrícia Nóbrega and Carlos Gonçalinho from CAM-FCG; Filipe Duarte from Serralves; Pedro Lapa and Francisca Sousa from MCB; and Adelaide Ginga from MNAC. This research was supported by Fundação para a Ciência e Tecnologia, Ministério da Ciência, Tecnologia e Ensino Superior (FCT/MCTES), Portugal, through CORES Ph.D. Doctoral Programme in the Conservation and Restoration of Cultural Heritage with the SFRH/BD/52318/2013 doctoral grant; through IF/00653/2015 and PTDC/ ART-OUT/29692/2017 project grants; and through the Associate Laboratory for Green Chemistry — LAQV (UIDB/50006/2020).

\section{REFERENCES}

1. Patkus, B., Assessing preservation needs. A self-survey guide, Northeast Document Conservation Center, Andover (2003).

2. Commonwealth Department of Communications, Information Technology and the Arts, ReCollections: Caring for collections across Australia: Managing Collections, Heritage Collections Council, Canberra (1998), https://aiccm.org.au/ sites/default/files/docs/reCollections/4_managing_collections.pdf (accessed 2019-09-16).

3. Then, E.; Oakley, V., 'A survey of plastic objects at the Victoria and Albert Museum', V\&A Conservation Journal 6 (1993) 11-14, http://www.vam.ac.uk/content/journals/conservation-journal/issue-06/a-survey-of-plastic-objects-at-the-victoria-and-albert-museum/ (accessed 2020-10-07).

4. Morgan, J., 'A survey of plastics in historical collections' (1994), http://web.archive.org/web/20061015204042/http:// www.plastiquarian.com/survey/survey.htm (accessed 2020-10-07).

5. Shashoua Y.; Ward, C., 'Plastics: modern resins with ageing problems', in Resins Ancient and Modern, ed. M. M. Wright and J. H. Townsend, SSCR, Edinburgh (1995) 33-37.

6. Keneghan, B., 'Plastics? - Not in my collection', V\&A Conservation Journal 21 (1996) 4-6, http://www.vam.ac.uk/content/journals/conservation-journal/issue-21/plastics-not-in-my-collection/ (accessed 2020-10-07).

7. Keneghan, B., 'Conservation: A survey of synthetic plastic and rubber objects in the collections of the Victoria and Albert Museum', Museum Management and Curatorship 19(3) (2001) 321-331, https://doi.org/10.1080/09647770101001903.

8. Williams, R.S., 'Care of plastics: malignant plastics', WAAC Newsletter 24(1) (2002), https://cool.conservation-us.org/waac/wn/wn24/wn24-1/wn24-102.html (accessed 2020-10-07).

9. Shashoua, Y., 'Conservation research in the 1990s', in Plastics collecting and conserving, ed. A. Quye; C. Williamson, NMS Publishing Limited, Edinburgh (1999) 105-110.

10. Kenenghan, B.; van Oosten, T.; Laganà, A.; Wagenaar, M.; Barabant, G.; Balcar, N.; Bluzat, H.; Bollard, C.; Fayein, J.; Kuperholc, S.; Ramel, S.; Lattuati-Derieux, A., 'In what condition are my artefacts? Case studies', in Preservation of Plastic Artefacts in Museum Collections, ed. B. Lavédrine, A. Fournier,
G. Martin, Éditions du comité des travaux historiques et scientifiques, Paris (2012) 109-137.

11. Schossler, P.; Mariano, C.V.; Carneiro, T.C.; Mendonça, V., 'Conservation of plastics at the Pinacoteca de São Paulo, Brazil', in Future Talks 013. Lectures and workshops on technology and conservation of modern materials in design, ed. T. Bechthold, Die Neue Sammlung - the International Design Museum, Munich (2015) 211-216.

12. Moomaw, K., 'A condition survey methodology and database for plastic objects at the Metropolitan Museum of Art', in Future Talks 009. The conservation of modern materials in applied arts and design, ed. T. Bechthold, Die Neue Sammlung - the International Design Museum, Munich (2011) 7-15.

13. Schertel, B., 'Meeting the needs of contemporary design: a new survey methodology', in Future Talks 009. The conservation of modern materials in applied arts and design, ed. T. Bechthold, Die Neue Sammlung - the International Design Museum, Munich (2011) 17-24.

14. Roth, K., Hausdorf, D., 'Capturing the state of preservation: a pdf-based survey method for surveying plastics at the Metropolitan Museum of Art', in Future Talks 017. The silver edition. Visions. Innovations in technology and conservation of the modern, ed. T. Bechthold, Die Neue Sammlung - the International Design Museum, Munich (2019) 11-18.

15. Brydson J. A., 'Acrylic Plastics', in Plastic Materials, 7th ed., Butterworth-Heinemann, Oxford (1999) 398-424.

16. Aftalion F., A History of the International Chemical Industry, 2nd ed., Chemical Heritage Press, Philadelphia (2001).

17. Painter, P. C.; Coleman, M. M., Essentials of polymer science and engineering; DEStech Publications, Lancaster (2009).

18. Waentig, F., Plastics in Art. A study from the conservation point of view, Michael Imhof Verlag, Petersberg (2008).

19. Albus, S.; Bonten, C.; Keßler, K.; Rossi, G.; Wessel, T., Plastic Art-A Precarious Success Story, AXA Art, Cologne (2007).

20. Blank, S., 'An introduction to plastics and rubbers in collections', Studies in Conservation 35(2) (1990) 53-63, https://doi. org/10.2307/1506193.

21. Melo, M. J.; Bracci, S.; Camaiti, M.; Chiantore, O.; Piacenti, F.; 'Photodegradation of acrylic resins used in the conservation of stone', Polymer Degradation and Stability 66(1) (1999) 23-30, https://doi.org/10.1016/S0141-3910(99)00048-8.

22. Ferreira J. L.; Melo M. J.; Ávila, M. J.; Ramos, A. M., 'The shadows by Lourdes Castro: a conservation study of PMMA in the 21st century', in Preprints of the ICOM-CC 16th Triennial Conference, Lisbon 2011, ed. J. Bridgland et al., ICOM, Lisbon (2011) paper 1005.

23. Babo, S.; Ferreira, J. L.; Ramos, A. M.; Micheluz, A.; Pamplona, M.; Casimiro, M. H.; Ferreira, L. M.; Melo, M. J., 'Characterization and Long-Term Stability of Historical PMMA: Impact of Additives and Acrylic Sheet Industrial Production Processes', Polymers 12(10) (2020) paper 2198, https://doi.org/10.3390/polym12102198.

24. Lavédrine, B.; Fournier, A.; Martin, G. (eds.), Preservation of Plastic Artefacts in Museum Collections, Éditions du comité des travaux historiques et scientifiques, Paris (2012).

25. Lorne, A., 'The poly(methyl methacrylate) objects in the collection of the Netherlands Institute for Cultural heritage', in Preprints of the ICOM-CC 12th Triennial Meeting, Lyon 1999, Ed. Bridgland, J., James \& James (Science Publishers) Ltd., London (1999) 871-875. 
26. 'The Collection', in Centro de Arte Moderna Gulbenkian, https://gulbenkian.pt/cam/en/the-collection/ (accessed 2021-07-04).

27. 'Museu Colecção Berardo', in The Berardo Collection, https:// www.berardocollection.com/?sid $=50004 \&$ CID $=102 \&$ lang $=\mathrm{pt}$ (accessed 2020-10-07).

28. 'Coleção', in Museu Nacional de Arte Contemporânea do Chiado, http://www.museuartecontemporanea.gov.pt/pt/museu/a-colecao (accessed 2020-10-07).

29. 'Coleção de arte', in Fundação EDP, https://www.fundacaoedp.pt/pt/conteudo/colecao-de-arte (accessed 2020-10-07).

30. 'Coleção', in Culturgest, https://www.culturgest.pt/pt/colecao/ (accessed 2020-10-07).

31. Gomes, S., 'Colecção Manuel de Brito. Inventário e conservação. Problemas e perspectivas', Estudos de Conservação e Restauro 1 (2009) 24-38, https://doi.org/10.34618/ecr.1.3163.

32. 'Coleção, Apresentação', in Serralves, https://www.serralves. pt/institucional-serralves/colecao-apresentacao/ (accessed 2020-10-07).

33. 'About the António Cachola Collection' (2016), in Colecção António Cachola, https://col-antoniocachola.com/?page $\mathrm{id}=7420$ \&lang=en (accessed 2020-10-07).

34. Shashoua, Y., Conservation of Plastics. Materials science, degradation and preservation, Butterworth, Oxford (2008).

35. Archer, M., Art Since 1960, 2nd ed., Thames \& Hudson, London (2002).

36. Ávila, M. J., 1960-1980, anos de normalização artística nas colecções do Museu do Chiado, IPM/MFTPJ, Castelo Branco (2003).
37. Penichon, S.; Jürgens, M., 'Issues in the Conservation of Contemporary Photographs: The Case of Diasec or FaceMounting', AIC News 27(2) (2002) 1-8.

38. Babo, S.; Ferreira, J. L.; Melo, M. J.; Ramos, A. M., 'Back to the origin: understanding the history of production and its influence on the properties of acrylic sheet', in Future Talks 015 - Processes. The making of design and modern art Materials, technologies and conservation strategies, ed. T. Bechthold, Die Neue Sammlung - the International Design Museum, Munich (2015) 160-70.

39. Angelin, E. M.; Babo, S.; Ferreira, J. L.; Melo, M. J., 'Raman microscopy for the identification of pearlescent pigments in acrylic works of art', Journal of Raman Spectroscopy 50(2) (2019) 232-241, https://doi.org/10.1002/jrs.5431.

RECEIVED: 2020.12.23

REVISED: 2021.05.21

ACCEPTED: 2021.06.10

ONLINE: 2021.07 .20

\section{(c) (1) (8) $\Theta$}

This work is licensed under the Creative Commons Attribution-NonCommercial-NoDerivatives 4.0 International License. To view a copy of this license, visit

http://creativecommons.org/licenses/by-nc-nd/4.o/deed.en. 